\title{
Bisphenol S Leads to Cytotoxicity-Induced Antioxidant Responses and Oxidative Stress in Isolated Rainbow Trout (Oncorhyncus Mykiss) Hepatocytes
}

\section{Burak Kaptaner ( $\sim$ bkaptaner@yyu.edu.tr )}

Van Yuzuncu Yil University https://orcid.org/0000-0003-2366-6756

\section{Can Yilmaz}

Yuzuncu Yil University: Van Yuzuncu Yil Universitesi

\section{Handan Aykut}

Yuzuncu Yil University: Van Yuzuncu Yil Universitesi

\section{Emine Doğan}

Yuzuncu Yil University: Van Yuzuncu Yil Universitesi

\section{Ceylan Fidan}

Yuzuncu Yil University: Van Yuzuncu Yil Universitesi

\section{Müşerref Bostancı}

Yuzuncu Yil University: Van Yuzuncu Yil Universitesi

\section{Fatoş Yıldız}

Yuzuncu Yil University: Van Yuzuncu Yil Universitesi

\section{Research Article}

Keywords: Bisphenol S, Oncorhyncus mykiss, fish hepatocytes, Cytotoxicity, Antioxidant defences

Posted Date: June 16th, 2021

DOl: https://doi.org/10.21203/rs.3.rs-607437/v1

License: (9) This work is licensed under a Creative Commons Attribution 4.0 International License.

Read Full License

Version of Record: A version of this preprint was published at Molecular Biology Reports on October 13th, 2021. See the published version at https://doi.org/10.1007/s11033-021-06771-6. 


\section{Abstract}

Background: Bisphenol S (BPS) is a chemical compound that is utilized in the plastic industry as an alternative to bisphenol A (BPA). The toxic effects of BPS in fish is less known and limited. Therefore, in the present study, it was aimed to investigate the influence of BPS on rainbow trout (Oncorhyncus mykiss) hepatocytes in vitro.

Methods and Results: For this purpose, the hepatocytes of the fish were isolated, and then the cultured cells were treated with increasing concentrations of $\operatorname{BPS}(0,15.63,31.25,62.50,125,250$, and $500 \mu \mathrm{M})$ for $24 \mathrm{~h}$. The cytotoxic impact of BPS was determined in the culture media using lactate dehydrogenase assay and then, the antioxidant defence indicators were assayed. The results showed that concentrationdependent increases were observed in the percentage of cytotoxicity. The superoxide dismutase activity was reduced, while the catalase and glutathione peroxidase activity was elevated with all of the BPS concentrations. The glutathione S-transferase (GST) activity was significantly increased with a BPS concentration of $31.25 \mu \mathrm{M}$ or higher, while GST theta 1-1 activity was decreased with the same concentrations of BPS. The reduced glutathione content was decreased significantly with a BPS concentration of $31.25 \mu \mathrm{M}$ or higher, and the malondialdehyde content increased with BPS concentrations of 125,250 , and $500 \mu \mathrm{M}$.

Conclusions: The findings determined herein suggested that BPS causes cytotoxicity in fish hepatocytes and could lead to oxidative stress, resulting hepatotoxicity in fish. Thus, the utilization of BPS instead of BPA as safe alternative in industry should be re-evaluated in the future for environmental health.

\section{Introduction}

It is well-known that bisphenol A (BPA) is a an endocrine-disrupting chemical, as well as a suspected carcinogen that is used in the production of plastic materials, food packaging, medical equipment, dental sealants, baby bottles, adhesives, flame retardants, toys, and thermal receipts [1, 2]. Due to its potential hazardous impacts in humans and risks to wildlife, scientific milieu and regulators have raised concerns regarding use of BPA throughout the world [3]. Consequently, efforts toward restriction and legislation for usage of BPA have been taken by the European Union and United States $[4,5]$ and safer alternatives have been sought instead of BPA in industrial applications. Thus, manufacturers have been prompted to replace BPA with its structural derivatives, such as bisphenol S (BPS), so as to comply with those regulations [6, 7]. BPS has been frequently utilized as an electroplating solvent, wash-fastening agent, and component of phenolic resin [8]. This analog is commonly used in daily products, such as epoxy glues, thermal receipts, canned food stuffs, paper currencies, luggage tags, food cartons, and baby bottles $[9,10,11]$. Products in which BPS has been used as a component, such as thermal papers and plastics, are labelled as 'BPA-free' in marketing [12]. Environmental monitoring studies have reported the presence of BPS in indoor dust, foodstuff, sediments, surface waters, and sewage sludges in different countries $[6,13,14]$. Average concentrations of BPS in the rivers of Japan, Korea, China, and India were reported to be detected from undermined levels, up to $15,42,135$, and $7200 \mathrm{ng} / \mathrm{L}$, respectively [14]. The 
estimated daily dietary intake ( $\mathrm{ng} / \mathrm{kg}$ body weight/day) of BPS for infants, toddlers, children, teenagers, and adults, were averagely determined to be $1.72,4.34,2.49,1.60$, and $1.31 \mathrm{ng} / \mathrm{kg}$ body weight, respectively, in the United States [13]. In the human urine samples that were examined in various countries around the world, BPS concentrations of $1.18 \mathrm{ng} / \mathrm{mL}, 0.933 \mu \mathrm{g} / \mathrm{g}$ creatinine (Cre) were determined in Japan, as well as $0.299 \mathrm{ng} / \mathrm{mL}, 0.304 \mu \mathrm{g} / \mathrm{g}$ Cre in the United States, $0.226 \mathrm{ng} / \mathrm{mL}, 0.223$ $\mu \mathrm{g} / \mathrm{g}$ Cre in China, $0.172 \mathrm{ng} / \mathrm{mL}, 0.126 \mu \mathrm{g} / \mathrm{g}$ Cre in Kuwait, and $0.160 \mathrm{ng} / \mathrm{mL}, 0.148 \mu \mathrm{g} / \mathrm{g}$ Cre in Vietnam. As inhabitants of aquatic environments, fish could be inevitably exposed to BPA and its analogs via their surrounding milieu. In a study that was recently, BPA was detected in the liver and muscle of Trachurus trachurus, Dicentrarchus labrax, and Scomber colias from the North East Atlantic Ocean, as well as bisphenol $B$ and bisphenol $E$ in the muscle [15]. Experimental studies over the last decade have shown that exposure to BPS causes developmental abnormalities, reproductive impairment, and hormonal imbalance in fish. The exposure of adult zebrafish pairs to concentrations of $0.5 \mu \mathrm{g} / \mathrm{L}$ to $50 \mu \mathrm{g} / \mathrm{L}$ of BPS has been reported to cause reduced egg production, increased 17ß-estradiol levels in both sexes, decreased testosterone levels accompanied by up-regulated cyp 19 and down-regulated cyp 17 and $17 \beta h s d$ transcripts, as a consequence of being influenced negatively of hypothalamic-pituitary-gonad axis, and a delayed rate of hatching. Moreover, hatchability success and malformations in F1 generation due to the impairment of development have also been reported [16]. The treatment of zebrafish (Danio rerio) with BPS resulted in a skewed sex ratio towards the side of females, low testosterone levels in males, significant escalations in plasma vitellogenin, decreased levels of plasma thyroxine and triiodothyronine, decreases in egg production and sperm count, and lower hatching rate [17]. Apart from these studies in fish, it was also documented that BPS depresses hematological functions and promotes cardiovascular function in Sprague-Dawley rats. BPS has been also reported to possess estrogenic, androgenic, and anti-androgenic activity, and genotoxic impacts [10, 18, 19, 20, 21].

The characterization of oxidative stress includes an imbalance between anti-oxidants and pro-oxidants that can be stimulated by xeno-estrogens and antioxidant system indicators, which are useful tools for the determination of harmful effects of a specific pollutant [22]. In a previous study, BPS was found to cause significant increases in intracellular reactive oxygen species (ROS) levels and glutathione Stransferase (GST) activity in the marine rotifer, Brachianus koreanus. Qiu et al. [23] reported that the exposure of fish (Cyprinus carpio) primary macrophages to low concentrations of BPS resulted in the generation of nitric oxide and ROS levels, increased total antioxidant capacity, and lipid peroxidation, as well as impaired phagocytic activity and the immune response involved in estrogen receptors. However, very scarce information regarding BPS cytotoxicity in fish is available in the literature data.

Fish cells are inexpensive and suitable tools that can be used for testing chemicals in toxicological studies [24]. Therefore, in this study, the isolated and primary cultured hepatocytes of Oncorhyncus mykiss were used, as a result of it being a test animal that was recommended for use in toxicological studies by the Organization for Economic Co-operation and Development [25], to shed light on the harmful effects of BPS at a cellular level. 


\section{Material And Method}

\section{Fish}

Five juvenile rainbow trout (Oncorhyncus mykiss) (fork length: $20-21.5 \mathrm{~cm}$; total weight: $106-136 \mathrm{~g}$ ) were used in the study. The fish were obtained from a locally owned rainbow trout farm that was located in Van Province, Turkey.

\section{Preparation Of Isolated Hepatocytes}

The process of hepatocyte isolation from the fish was performed using the method given tin the study of Mortensen et al. (2006) [26], with some modifications. First, the livers were aseptically dissected from the fish and put into Petri dishes that contained cold $\mathrm{Ca}^{2+}{ }^{2}$ free solution-I $(7.14 \mathrm{~g} / \mathrm{L}$ of $\mathrm{NaCl}, 0.36 \mathrm{~g} / \mathrm{L}$ of KCl, $0.15 \mathrm{~g} / \mathrm{L}$ of $\mathrm{MgSO}_{4}, 1.6 \mathrm{~g} / \mathrm{L}$ of $\mathrm{Na}_{2} \mathrm{HPO}_{4}, 0.4 \mathrm{~g} / \mathrm{L}$ of $\mathrm{NaH}_{2} \mathrm{HPO}_{4}, 0.31 \mathrm{~g} / \mathrm{L}$ of $\mathrm{NaHCO}_{3}$, and $20 \mathrm{mg} / \mathrm{L}$ of EGTA). Next, the samples of liver tissue were minced while still in this solution, and then all of the blood was removed, as well as any remaining rude components of tissue, such as connective tissue and vessels. As a next step, the liver was dissociated mechanically into even smaller pieces via the use of surgical blades and fine forceps. Next, pieces of tissue, which were now whitened, were transferred into solution-II, which possessed of the same compounds that were included in solution-I, with the addition of $0.11 \mathrm{~g} / \mathrm{L}$ of $\mathrm{CaCl}_{2}$ rather than EGTA, as well as $0.025 \mathrm{mg} / \mathrm{mL}$ of type IV collagenase, which was used to break the $\mathrm{Ca}^{2+}$-dependent cell-cell connections and enzymatically dissociate the cells. After the pieces of tissue had been softened in solution-II for $10 \mathrm{~min}$, they were pulverized using pipette tips of varying sizes. Next, the crude particles were then removed via the use of a stainless steel sieve and the cell suspension that it yielded was very carefully passed through a sterile injector needle to further dislocate the cells. Then, the suspension was placed into Eppendorf tubes, which were then centrifuged at $60 \times g$ for 3 min. The cell pellet was then suspended in Leibovitz (L-15) medium containing $0.38 \mathrm{~g} / \mathrm{L}$ of $\mathrm{NaHCO} 3$ and $1 \%$ $(\mathrm{v} / \mathrm{v})$ antibiotic-antimycotic. After it had been washed for the second time with $\mathrm{L}-15$, the cells were resuspended in medium. After this, the cells were counted by using a Thoma slide, and the cell viability was assessed using the Trypan blue exclusion test. In the examination of the cell culture, the cells were observed to determine if they possessed $>90 \%$ viability.

\section{Hepatocyte Culture And Bps Treatment}

The isolated hepatocytes were seeded into 24-well culture plates that were coated with collagen-I (Gibco, Catalogue Number: A11428-02, Thermo Fisher Scientific Inc., Waltham, MA, USA) in $1 \mathrm{~mL}$ of medium that contained a cell density of $2 \times 10^{6}$ per each well. The cells were maintained at a temperature of $14^{\circ} \mathrm{C}$ for $48 \mathrm{~h}$ in an incubator under sterile conditions (Binder $\mathrm{GmbH}$, Tuttlingen, Germany) with atmospheric air and saturated humidity prior to treatment with BPS. A $0.1 \mathrm{M}$ stock solution of $\mathrm{BPS}\left(\mathrm{C}_{12} \mathrm{H}_{10} \mathrm{O}_{4} \mathrm{~S}\right.$; MW: 250.27; 99.7\%, Acros Organics, Catalogue Number: 146915000) was prepared in absolute ethanol and 
exposure media that contained $15.63,31.25,62.50,125,250$, and $500 \mu \mathrm{M}$ concentrations of BPS, which were then applied to the cells for a period of $24 \mathrm{~h}$. Care was taken to ensure that the final ethanol concentration in the media was not greater than $0.5 \%$. In the control group, the cells were treated with L15 medium that only contained $0.5 \%$ absolute ethanol. Five replicate wells were constructed for the experimental groups. A Leica DMI 6100B inverted microscope (Leica Microsystems GmbH, Wetzlar, Germany) was used to check the cell cultures.

\section{Lactate Dehydrogenase Cytotoxicity Test}

The culture media was examined to determine the amount of lactate dehydrogenase (LDH) leakage that had occurred, and this measurement was then used in the determination of the cytotoxic effects that resulted from the BPF following treatment for $24 \mathrm{~h}$. After the treatments had been completed, removal of the culture media from the wells was performed, which was then transferred into Eppendorf tubes. Following this, $10 \mu \mathrm{L}$ of the samples was put into a 96-well plate and an assay kit to determine LDH cytotoxicity (Catalog no: ab65393, Abcam, Cambridge, UK) was then used to conduct an assay of the LDH activity, following the manufacturer's instructions. As a final step, a DAS A3 ELISA plate reader (DAS Rome, Italy) was used in the measurement of the optic density (OD) values, which was performed at 450 $\mathrm{nm}$. In each of the experiments, 5 replicates were conducted. All measurements conducted were in duplicate, and calculation of the percentage of cytotoxicity was done using the formula that was provided in the kit procedures for each sample, as given in Eq. (1):

$$
\text { Cytotoxicity }(\%)=\frac{(\text { OD of the test sample OD of the low-control well })}{(\text { OD of the high-control well OD of the low-control well })} \times 100
$$

\section{Measurement Of Antioxidant Defense Indicators}

After the exposures had been completed, the culture media very carefully pipetted out of the wells and the hepatocytes were then rinsed in $1 \mathrm{~mL}$ of ice-cold phosphate buffered saline that had a pH of 7.4. Then, the obtained $2 \times 10^{-6} / \mathrm{mL}$ cell suspensions were transferred into Eppendorf tubes, which were then lysed in a glass-porcelain ultrasonic homogenizer (Jencons Scientific Co., Herts, UK). Next, the homogenate was then centrifuged at $15,000 \times \mathrm{g}$ for $15 \mathrm{~min}$. All of these procedures were either conducted at $4^{\circ} \mathrm{C}$ or on ice. As the next step, the supernatant fractions were taken out and then used to determine the antioxidant defense indicators. In each of the experiments, 5 replicates were conducted.

Spectrophotometric measurement of the SOD activity was conducted with a commercial kit (Ransod, Randox Lab., Crumlin, County Antrim, UK) by following the manufacturer's instructions. The method listed in the kit, which followed that given by Suttle and McMurray [27], consisted of an xanthine-xanthine oxidase system that was utilized in the generation of superoxide radicals, which reacted with 2-(4- 
iodophenyl)-3-(4-nitrophenol)-5-phenyltetrazolium chloride (INT) and resulted in the formation of red formazan dye. Measurement of the SOD activity was then conducted using the degree of inhibition determined from this reaction. It was determined that 1 unit of SOD was the amount to result in $50 \%$ inhibition of the reduction rate of INT under the conditions that were given in the assay. All of the measurements were conducted at $37^{\circ} \mathrm{C}$ and $505 \mathrm{~nm}$, and the activity was expressed as unit/mg protein.

Spectrophotometric measurement of the catalase (CAT) activity was performed using the method given by Aebi [28]. The CAT activity was determined via an assay of the decrease of the consumption of $\mathrm{H}_{2} \mathrm{O}_{2}$ at $240 \mathrm{~nm}$. CAT activity was expressed as nmole of $\mathrm{H}_{2} \mathrm{O}_{2}$ consumed/min/gram of protein.

Measurement of the glutathione peroxidase (GPx) activity was performed using a commercial obtained Ransel kit (Randox Laboratories Ltd., Co. Antrim, UK) $37^{\circ} \mathrm{C}$ and $340 \mathrm{~nm}$, following the manufacturer's instructions. This assay followed the method given by Paglia and Valentine [29]. The oxidation of glutathione is catalyzes by GPx via cumene hydroperoxide. When glutathione reductase and NADPH are present, the glutathione that has been oxidized (GSSG) is converted immediately into its reduced form, with the concomitant oxidation of NADPH to NADP+. Calculation of the GPx activity was performed from the decreases observed in the absorbance values. Expression of the GPx activity was given as units per grams of protein.

Determination of glutathione S-transferase (GST) activity was performed in line with the method given by Habig et al. [30]. Optimization was performed for this using the ELISA Microplate Reader System, which was used on a Multiskan FC microplate photometer (Thermo Fisher Scientific Inc., Waltham, MA, USA) (Yilmaz and Işcan, 2014) [31]. The contents of the reaction medium for the total GST activity measurements were $0.1 \mathrm{M}$ of phosphate buffer at a pH of 7.4, $1 \mathrm{mM}$ of 1-chloro-2,4-dinitrobenzene, and 1 $\mathrm{mM}$ of GSH. The reaction was started through the addition of $25 \mu \mathrm{L}$ of the sample, which comprised 33.28-73.4 $\mu$ g per well, and the absorbance data were obtained at $25^{\circ} \mathrm{C}$, for $10 \mathrm{~min}$, at $340 \mathrm{~nm}$

The contents of the reaction medium for the GSTT1- 1 isozyme activity measurements were $0.1 \mathrm{M}$ of phosphate buffer at a pH of 6.5, $0.25 \mathrm{mM}$ of 1,2 -epoxy-3-(p-nitrophenoxy)-propane, and $0.5 \mathrm{mM}$ of GSH. The reaction was started through the addition of $100 \mu \mathrm{L}$ of the sample, which comprised 133.2-293.6 $\mu \mathrm{g}$ per well, and the absorbance data were obtained at $360 \mathrm{~nm}$, for $10 \mathrm{~min}$, at $25^{\circ} \mathrm{C}$ [32]. Specific activity was calculated by using Eq. (2):

$$
\text { Specificactivity }=\frac{\Delta \mathrm{A} / \Delta \mathrm{t}}{\epsilon\left(\mathrm{mM}^{-1} \mathrm{~cm}^{-1}\right)} \times \mathrm{DF} \times \frac{1}{\text { mgofprotein } / \mathrm{mL}}
$$

2

Here, $\Delta \mathrm{A} / \Delta \mathrm{t}$ is the absorbance change per minute, $\varepsilon$ is the extinction coefficient of the substrates (9.6 $\mathrm{mM}^{-1} \mathrm{~cm}^{-1}$ for CDNB and $0.5 \mathrm{mM}^{-1} \mathrm{~cm}^{-1}$ for EPNP), and DF is the dilution factor. 
Determination of the total thiol content was performed following the method that was described by Sedlak and Lindsay [33], which had been optimized for the ELISA Microplate Reader System. The standard curve was built with the measurement results of the GSH standards in the concentration range of 0.1-1 mM. Next, $50 \mu \mathrm{L}$ of sample, comprising $66.6-146.8 \mu \mathrm{g} /$ well, was added to $30 \mu \mathrm{L}$ of $0.2 \mathrm{M}$ Tris buffer at a pH of 8.2. Right after that, $20 \mu \mathrm{L}$ of $2 \mathrm{mM} \mathrm{5,5'-Dithiobis-(2-Nitrobenzoic} \mathrm{acid)} \mathrm{(DTNB)} \mathrm{and} 100$ $\mu \mathrm{L}$ of methyl alcohol were added into each of the wells. The plate was then incubated, under dark conditions, for $30 \mathrm{~min}$ at $25^{\circ} \mathrm{C}$. The absorbance was measured at $405 \mathrm{~nm}$. Calculation of the total amount of thiol within the samples was performed by using the slope value of the standard curve, the results of which were expressed as nmole/mg of protein.

The content of malondialdehyde (MDA), which is a product of lipid peroxidation, was spectrophotometrically measured at $532 \mathrm{~nm}$, following the method of Beuge and Aust [34]. Briefly, $0.1 \mathrm{~mL}$ of $150 \mathrm{mM}$ Tris-HCl buffer, at a pH of 7.1, was added on the supernatant $(0.1 \mathrm{~mL})$. Next, $0.1 \mathrm{~mL}$ of 1.5 $\mathrm{mM}$ ascorbic acid and $0.1 \mathrm{~mL} 1 \mathrm{mM} \mathrm{FeSO}_{4}$ were added to this mixture. The total volume of this mixture was completed to $1 \mathrm{~mL}$ with addition of distilled water and then the tubes were incubated for $15 \mathrm{~min}$ at $37^{\circ} \mathrm{C}$. As a next step, $1 \mathrm{~mL}$ of trichloroacetic acid (10\%) and $2 \mathrm{~mL}$ of thiobarbituric acid $(0.375 \%)$ were added to the mixture, and the tubes were incubated in boiling hot water for $15 \mathrm{~min}$. After the tubes had been cooled, centrifugation was performed at $3000 \mathrm{rpm}$ for $10 \mathrm{~min}$. Spectrophotometric measurements were carried out at $505 \mathrm{~nm}$. Calculation of the concentration of MDA in samples was performed using the standard curve that was derived from external 1,1,3,3-tetraethoxypropane standards. The results were expressed as nmole/mg of protein.

Spectrophotometric assay of the total protein content within the supernatant fractions was performed using the method that was given by Bradford [35], using bovine serum albumin as the standard.

\section{Statistical Analyses}

All of the statistical analyses were conducted using IBM SPSS Statistics for Windows 20.0 (IBM Corp., Armonk, NY, USA). One-way ANOVA and the Duncan multiple comparison post-hoc test were used to analyze differences among the groups. The results were expressed as the mean \pm the standard error of the mean (SEM). $P<0.05$ was considered statistically significant.

\section{Results}

After the experiments had been completed, it was observed in the microscopic examination of the cells that the hepatocytes in the control group exhibited a healthy appearance (Fig. 1a). The hepatocytes that has been treated exhibited degenerative changes, such as apoptotic figures or shrinkage, and they had did not have as healthy of an appearance as the cells in the control group (Fig. 1b).

As a result of the treatment that were applied in this study, it was observed that all of the BPF concentrations resulted in a significant increase LDH leakage into the media. The percentage of cellular 
cytotoxicity increased gradually with the increasing BPS concentrations $(P<0.05)$. It was observed that cytotoxicity was occurred with BPS concentrations of $1.34 \pm 0.31 \%, 7.23 \pm 0.15 \%, 8.61 \pm 0.30 \%, 10.17 \pm$ $0.81 \%, 13.71 \pm 0.67 \%$, and $18.00 \pm 1.18 \%$ with $15.63,31.25,62.50,125,250$, and $500 \mu \mathrm{M}$, respectively (Fig. 2). All of the increased levels of cytotoxicity were determined to be statistically significant, except for the $15.63 \mu \mathrm{M}$ concentration of BPS

The hepatocyte SOD activity exhibited a significant decrease ( $P<0.05$; Fig. 3a), whereas the CAT activity was observed to significantly increase $(P<0.05 ;$ Fig. $3 b)$. The GPx activity was significantly increased with all of the BPS concentrations (Fig. 4a; $P<0.05$ ). The total GST specific activity was also detected to be elevated $(P<0.05)$ by the increasing amount of BPS in the growth media. On the contrary, specific activity of GSTT1-1 isozyme in the samples, except the one that had the lowest BPS concentration, of $15.63 \mu \mathrm{M}$, were all lower than $(\mathrm{P}<0.05)$ those that were in the control group (Figs. $4 \mathrm{~b}, \mathrm{C})$. An alteration similar to the change in the GSTT1-1 isozyme was observed in the amount of total thiol groups considered as an indicator of the GSH pool of the cell. It was determined that the GSH pool shrank $(\mathrm{P}<$ 0.05) in all treatment groups in all of the experimental groups, relative to the control group, except for the one that was treated with the lowest BPS concentration (Fig. 5a). The MDA content remained unchanged with $15.63,31.25$, and $62.50 \mu \mathrm{M}$ concentrations of BPS, while it displayed statistically significantly increases with 125,250 , and $500 \mu \mathrm{M}$ concentrations of BPS (Fig. 5b).

\section{Discussion}

The percentage of hepatocyte cytotoxicity was gradually increased after the BPS treatment according to the LDH cytotoxicity test. Those increases were statistically significant with concentrations of $31.25 \mu \mathrm{M}$ or higher, and it was determined that the percentage of cytotoxicity was $17.01 \%$ following treatment with the highest concentration of BPS. Similar results were also reported in several studies using different techniques, wherein BPS induced cytotoxicity or decreased cell viability in different cell types. For example, Hercog et al. [36] found that BPS decreased cell viability in human hepatocellular carcinoma cells with a BPS concentration of $20 \mu \mathrm{g} / \mathrm{mL}$ after $72 \mathrm{~h}$ exposure. In a study by Kose et al. [37], cell viability was gradually descended in RWPE-1 cells after exposure to BPS for $24 \mathrm{~h}$, with between 0 and $600 \mu \mathrm{M}$ concentrations, and they determined that the inhibitory concentration at values of 20 and 50 for BPS was 108 and $380.90 \mu \mathrm{M}$, respectively. The percentage of cell viability was decrease to $61.30 \%$ in TM3 Leydig cells that had been treated with a $50 \mu \mathrm{g} / \mathrm{mL}$ concentration of BPS for $24 \mathrm{~h}$ [38]. These different results, even at similar concentrations, among studies regarding the percentage of cellular viability or cytotoxicity of BPS on cells might have resulted from the cell type, experimental design of the study, duration of treatment used, and the assays that were selected in the determination of cytotoxicity. Supportably, Russo et al. [39] reported that different cell types displayed different sensitivities to BPA and its analogs, and they also reported that the 48-h inhibitory concentrations of $50 \mu \mathrm{g} / \mathrm{mL}$ of BPS for 3T3-L1, MCF-7, C6, and HeLa cells were $>100 \mu \mathrm{M},>100 \mu \mathrm{M}, 168.4 \mu \mathrm{M}$, and $299.3 \mu \mathrm{M}$, respectively.

SOD and CAT constitute the first barrier for the elimination of superoxide radicals, as well as hydrogen peroxide, in the antioxidant system. As a free radical scavenging enzyme, SOD is responsible for the 
dismutation of highly-reactive and toxic superoxide anions into molecular oxygen and hydrogen peroxide. The current results showed that all of the concentration of BPS led to general decreases in the SOD activity. In accordance with the results determined herein, lower SOD activity were determined in the reproductive tissues of male rat offspring that had been exposed to BPA and its analogs including BPS. The levels of SOD activity were also reduced in human red blood cells treated with BPA, BPAF, and BPF for 4 and $24 \mathrm{~h}$, whereas BPS did not create significant changes in the SOD activity [40]. Kose et al. [37] also reported diminished SOD activity in RWPE-1 cells that had been incubated with BPA and BPF for 24 h, except for BPS. The differences between the studies may have arisen from the susceptibility of the cell types to BPS or the severity of the oxidative stress by BPS. A probable reason for deceased SOD activity in this study might have arisen from the excessive production of superoxide anions as a result BPS exposure, as the substrate of the enzyme might behaved as an oxidant [41]. SOD is susceptible to oxidation and it was demonstrated that the enzyme was inactivated by hydrogen peroxide [42]. Dimitrova et al. [43] reported that superoxide radicals or the generated hydrogen peroxide via superoxide radical transformation might have caused oxidation of the cysteine in the enzyme that resulted in decreased SOD activity. Thus, increased levels of superoxide anions or excessive hydrogen peroxide levels in the hepatocytes after BPS exposure might have caused such an effect in the current study. CAT, which is an essential antioxidant enzyme for cells, degrades hydrogen peroxide into $\mathrm{H}_{2} \mathrm{O}$ and oxygen. The generating hydrogen peroxide induces the activity of the enzyme. It was reported that CAT activity was elevated in mouse liver and renal cells after incubation for $12 \mathrm{~h}$ with BPS depending on the ROS production in those cells. In addition, BPS is capable of interacting with the enzyme via binding to the Gly 117 residue on the substrate channel, thus effecting hydrogen bonding networks [43]. Supporting those findings, the results determined herein showed that the exposure of rainbow trout hepatocytes to BPS influenced the CAT activity. Elevated CAT activity in the cells suggested that the enzyme was capable of eliminating of hydrogen peroxide, even in the presence of the decreased SOD activity [45]. The removal of toxic hydrogen peroxide and a wide variety of organic peroxides, which are produced as a consequence of oxygen metabolism, is carried out by the selenium-dependent antioxidant enzyme GPx. The enzyme acts as ROS scavenger in cells and uses GSH as a substrate during those processes. Exposure of human red blood cells to a BPS concentration of $500 \mu \mathrm{g} / \mathrm{L}$ for $4 \mathrm{~h}$ caused a significant decrease in the GPx activity, while no change was observed at the end of $24 \mathrm{~h}$ with the same concentration [40]. In another study, a significant reduction in the GPx activity was reported in RWPE-1 cells that were exposed to a BPS concentration of $108 \mu \mathrm{M}$ for $24 \mathrm{~h}$ [37]. These reports indicated that the sensitivity or compensation role of GPx against BPS cytotoxicity might have changed with treatment using different concentrations and time intervals according to the cell type. On the other hand, in this study, significant increases in the GPX activity were determined at all of exposure concentrations of BPS. The findings herein were more likely to be related with the production of hydrogen peroxide or other organic peroxides, or with the protective role of the enzyme against cellular membrane damage. Supporting the current study results, similar findings were also determined following 24-h treatment with BPF in rainbow trout hepatocytes [46].

GSH is a part of the second-line of antioxidant defense. This ubiquitous tripeptide (L-glutamine, cysteine, and glycine), which is usually the most prevalent intracellular thiol, can react directly or indirectly with 
ROS and during the metabolic free radical scavenging role of GSH, the sulfhydryl group of the molecule transforms into an oxidized GSH (GSSG) disulfide compound [47]. Both increased and decreased levels of GSH in cells are considered to be indicators of oxidative stress, of which increases occur under mild oxidative stress, depending on the compensation function of the molecule against free radicals, as a result of adaptive mechanisms including its synthesis, while its level could be decreased under severe oxidative stress because of disturbed adaptation mechanisms [48]. In the research conducted herein, GSH content was decreased with a BPS concentration of $125 \mu \mathrm{M}$ or higher, which suggested the presence of oxidative stress. In parallel with those findings, significant reductions in the GSH content was reported in zebrafish (Danio rerio) embryos after a short time exposure to BPA. Maćczak et al. [40] reported that BPA and its analogs, including BPAF and BPF, except for BPS, induced the strongest decreases in human red blood cells. However, elevated GSH levels were found in RWPE-1 cells that were exposed to BPS [37]. GSH is used by GST and GPx as a conjugating molecule, which aids in the facilitation of the hazardous effects of xenobiotics [49]. Decreased GSH content may result from an increase in the use of GSH by both GST and GPx, as well as the insufficient synthesis of GSH by glutathione reductase [45, 50-52]. In parallel with the literature data, concomitant increases were observed in the GST and GPx activity in the hepatocytes with reduced GSH levels in this study. Thus, it can be concluded that GSH was decreased as a consequence of the disturbance of its synthesis due to its failure to have an adaptive mechanism or increase in the molecule by the enzymes GST and GPX.

The up-regulation of some genes, which have vital functions in drug/xenobiotic metabolism and antioxidant defense system, such as UDP-glucuronosyltransferase, CAT and GST, were reported in the liver of marine fish Paralichthys olivaceus after exposure to BPS [53]. Moreover, 12-24 h of incubation with BPA caused the upregulation of GSTM in another marine fish, Kryptolebias marmoratus [54]. Similar results were also reported as elevated GST specific activity in the liver tissues of freshwater species like Pimephales promelas (Zare et al. 2018) [55] and Oryzias latipes [56]. In the current study, BPS treatment of Oncorhyncus mykiss hepatocyte culture unveiled the very same response of elevated total GST specific activity, demonstrating the practicality of the usage of this parameter in the testing of damage of xenobiotic exposure to aquatic animals. There have been such dose-responsive in vivo studies conducted to reveal the effects of BPS on marine organisms; however, the number of studies based on the application of this chemical directly onto hepatocyte cultures is very limited. The study of the function and nature of GSTs in the liver tissues of aquatic organisms in a cause and effect relation could enable the determination of the dimension of the problem created by BPA and its derivatives, like BPS.

GST theta is known as the first isozyme evolved among others, which consists of 2 different types: GSTT1 and GSTT2, sharing 55\% protein sequence identity, and, to date, it has been subjected to characterization in several aquatic organisms, such as Macrobrachium rosenbergii, Ruditapes philippinarum, and Apostichopus japonicus [57]. Although its major sites of expression are the gills and epithelium in the olfactory and digestive systems of rainbow trout [58], weak but debatable specific activity of GSTT1-1 was measured in the liver hepatocyte culture for the first time in this current study. GST theta types have been considered to play a role in xenobiotic biodegradation, even though their substrate specificities are different from each other [59], which might explain the decrease in the 
measured specific activity with the increasing BPS concentration in the media, while the total GST activity was scaled up in the treatment groups.

Oxidants, including radicals and ROS, may attack carbon-carbon double-bond-containing lipids, such as polyunsaturated fatty acids in biological membranes. During the oxidation of unsaturated fatty acids, a range of changes, including hydrogen removal from a carbon and the insertion of oxygen instead of it, occurs in target lipids involving glycolipids, phospholipids, and cholesterol. Finally, lipid peroxyl radicals as well as hydroperoxides cause an impairment in membrane function and leads to apoptosis in cells [60]. Among lipid peroxidation products, MDA is the most mutagenic and it has been widely used as a biomarker, which reflects indirectly the lipid peroxidation levels following free radical attacks in cells [61]. The findings determined in the current research displayed clearly that there was a significant elevation in the MDA content with concentrations of $125 \mu \mathrm{M}$ or higher of BPS, and those increases were observed to be correlated inversely with the decreases in the GSH levels. Similar to the results herein, rat spermatozoa displayed high ROS and thiobarbituric acid reactive substances (TBARS) levels after incubation with BPS [62]. In another study, the incubation of rat testicular tissue with BPS for $2 \mathrm{~h}$ caused the formation of ROS as well as an increase in lipid peroxidation level in vitro [63]. Ullah et al. [64] found increased lipid peroxidation levels quantified by TBARS in the reproductive tissues of the male offspring of Sprague Dawley rats that were exposed to BPA, and its analogs, with concomitant increases in the ROS levels, indicating that the accumulation of ROS could attack unsaturated fatty acids, and finally, lead to lipid peroxidation as the result of BPS. On the other hand, Maćczak et al. [40] stated that BPA and its analogs, BPAF, BPF, and BPS, induced ROS levels in red blood cells, whereas BPS did not cause increased lipid peroxidation, as was induced by BPA and the other analogs. Russo et al. [39] reported that the cytotoxicity of bisphenol analogs was slightly related with phospholipophilicity in different cell lines. Thus, it can be concluded that significant increases in the MDA content observed in this study might have arisen from the elevated levels of ROS, caused by BPS, which lead to accelerated lipid peroxidation.

In summary, the present research is the first report to demonstrate toxic effects of BPS on isolated rainbow trout hepatocytes. BPS, used as a substitute instead of BPA as an alternative in the food packaging or other application areas of industry, changed the levels of antioxidant defense enzymes, namely SOD, CAT, GPx, GST, and GSTT1, decreased the GSH content, and caused lipid peroxidation in the cells. The results provided evidences that BPS is not a safer alternative or innocent agent that can be used as an alternative to BPA. Authorities should reconsider the utilization of BPS in the industry and take measures to prevent environmental contamination of this compound, which may affect the antioxidant system in organisms.

\section{Declarations}

\section{Author Contributions}

This research was conceived by BK. The isolation and culturing of the hepatocytes, and the application of the treatments were performed by BK, HA, ED, MB and FY. The cytotoxicity testing was performed by BK, 
HA, ED, and FY. The antioxidant defense system indicators were measured by BK, CY, HA, ED, CF, FY, and $\mathrm{MB}$. Analyzing of the data and interpreting the results were performed by BK and CY. The drafting and editing of the manuscript were performed by BK and CY. The manuscript was finalized by BK.

\section{Funding}

The authors declare that no financial support was received for either the research or the writing of this article.

\section{Compliance with Ethical Standards}

Ethical approval The procedures that were conducted within this research were all performed in line with the procedures set forth by the National and Institutional Regulations for the Protection of Animal Welfare. The necessary permissions were obtained from the Ethical Committee of the Animal Experiments Ethics Committee of Van Yuzuncu Yil University, under decision No.: 2021/03-15 and protocol No.: E.37149.

Conflict of Interest The authors declare that they have no conflicts of interest with regards to this research.

\section{Data availability}

All of the data and the material that were used and analyzed in the course of the study herein can be obtained from the author for correspondence upon reasonable request.

\section{References}

1. Staples CA, Dorn PB, Klecka GM, O'Block ST, Harris LR (1998) A review of the environmental fate, effects and exposures of bisphenol A. Chemosphere 36:2149-2173

2. Seachrist DD, Bonk KW, Ho SM, Prins GS, Soto AM, Keri RA (2016) A review of the carcinogenic potential of bisphenol A. Reprod Toxicol 59:167-182. https://doi.org/10.1016/j.reprotox.2015.09.006

3. Rochester JR, Bolden AL (2015) Bisphenol S and F: a systematic review and comparison of the hormonal activity of bisphenol A substitutes. Environ Health Perspect 123(7):643-650. https://doi.org/10.1289/ehp.1408989

4. European Union (2011) Amending Directive 2002/72/EC as Regards the Restriction of Use of Bisphenol a in Plastic Infant Feeding Bottles, Commission Directive 2011/8/EU of 28 January 2011

5. US Food and Drug Administration (2013) Amended the Regulation 21 CFR175 as Regards No Longer Use Bisphenol a in the Coating. of Packaging for Powdered and Liquid Infant Formula

6. Liao C, Liu F, Alomirah H, Loi VD, Mohd MA, Moon H al (2012a) Bisphenol S in urine from the United States and seven Asian countries: occurrence and human exposures. Environ Sci Technol 46:68606866 
7. Liao C, Liu F, Guo Y, Moon HB, Nakata H, Wu Q et al (2012b) Occurrence of eight bisphenol analogues in indoor dust from the United States and several Asian countries: implications for human exposure. Environ Sci Technol 46:9138-9145

8. Clark E (2012) Sulfolane and sulfones. In: Kirk-Othmer Encyclopedia of Chemical Technology. John Wiley \& Sons, New York

9. Vinas P, Campillo N, Martínez-Castillo N, Hernández-Córdoba M (2010) Comparison of two derivatization-based methods for solid-phase micro extraction-gas chromatography-mass spectrometric determination of bisphenol $\mathrm{A}$, bisphenol $\mathrm{S}$ and bisphenol migrated from food cans. Anal Bioanal Chem 397:115-125

10. Grignard E, Lapenna S, Bremer S (2012) Weak estrogenic transcriptional activities of bisphenol A and bisphenol S. Toxicol In Vitro 26(5):727-731

11. Liao C, Li F, Kannan K (2012c) Bisphenol S, a new bisphenol analogue, in paper products and currency bills and its association with bisphenol a residues. Environ Sci Technol 46:6515-6522

12. Atlas E, Dimitrova V (2019) Bisphenol $S$ and bisphenol A disrupt morphogenesis of MCF-12A human mammary epithelial cells. Sci Rep 9(1):1-10

13. Liao CY, Kannan K (2013) Concentrations and Profiles of bisphenol A and other bisphenol analogues in foodstuffs from the United States and their implications for Human Exposure. J Agric Food Chem 61(19):4655-4662

14. Yamazaki E, Yamashita N, Taniyasu S, Lam J, Lam PK, Moon H al (2015) Bisphenol A and other bisphenol analogues including BPS and BPF in surface water samples from Japan, China, Korea and India. Ecotoxicol Environ Saf 122:565-572

15. Barboza LGA, Cunha SC, Monteiro C, Fernandes JO, Guilhermino L (2020) Bisphenol A and its analogs in muscle and liver of fish from the North East Atlantic Ocean in relation to microplastic contamination. Exposure and risk to human consumers. J Hazard Mater 393:22419. https://doi.org/10.1016/j.jhazmat.2020.122419

16. Ji K, Hong S, Kho Y, Choi K (2013) Effects of bisphenol S exposure on endocrine functions and reproduction of zebrafish. Environ Sci Technol 47(15):8793-8800

17. Naderi M, Wong MY, Gholami F (2014) Developmental exposure of zebrafish (Danio rerio) to bisphenol-S impairs subsequent reproduction potential and hormonal balance in adults. Aquat Toxicol 148:195-203

18. Molina-Molina JM, Amaya E, Grimaldi M, Saenz JM, Real M, Fernandez M et al (2013) In vitro study on the agonistic and antagonistic activities of bisphenol-S and other bisphenol-A congeners and derivatives via nuclear receptors. Toxicol Appl Pharmacol 272(1):127-136

19. Kitamura S, Suzuki T, Sanoh S, Kohta R, Jinno N, Sugihara K et al (2005) Comparative study of the endocrine-disrupting activity of bisphenol A and 19 related compounds. Toxicol Sci 84:249-259

20. Fic A, Zegura B, Dolenc MS, Filipic M, Masic LP (2013) Mutagenicity and DNA damage of bisphenol A and its structural analogues in HepG2 cells. Arh Hig Rada Toksikol 64(2):189-200. https://doi.org/10.2478/10004-1254-64-2013-2319 
21. Le Fol V, Aït-Aïssa S, Sonavane M, Porcher JM, Balaguer P, Cravedi JP et al (2017) In vitro and in vivo estrogenic activity of BPA, BPF, and BPS in zebrafish-specific assays. Ecotoxicol Environ Saf 142:150-156

22. Valavanidis A, Vlahogianni T, Dassenakis M, Scoullos M (2006) Molecular biomarkers of oxidative stress in aquatic organisms in relation to toxic environmental pollutants. Ecotoxicol Environ Saf 64(2):178-189

23. Qiu W, Yang M, Liu S, Lei P, Hu L, Chen B et al (2018) Toxic effects of bisphenol S showing immunomodulation in fish macrophages. Environ Sci Technol 52(2):831-838

24. Bols NC, Dayeh VR, Lee LEJ, Schirmer K (2005) Use of fish cell lines in the toxicology and ecotoxicology of fish. piscine cell lines in environmental toxicology. In: Mommsen TP, Moon TW (eds) Biochemistry and Molecular Biology of Fishes, Elsevier BV vol 6 pp 43-84. https://doi.org/10.1016/S1873-0140(05)80005-0

25. OECD (2019) Test no. 203: fish, acute toxicity test. OECD guidelines for the testing of chemicals, Sect. 2. OECD Publishing, Paris. https://doi.org/10.1787/9789264069961-en

26. Mortensen AS, Tolfsen CC, Arukwe A (2006) Gene expression patterns in estrogen (nonylphenol) and aryl hydrocarbon receptor agonists (PCB-77) interaction using rainbow trout (Oncorhynchus mykiss) primary hepatocyte culture. J Toxicol Environ Health 69(1-2):1-19. https://doi.org/10.1080/15287390500257792

27. Suttle NF, McMurray CH (1983) Use of erythrocyte copper:zinc superoxide dismutase activity and hair or fleece copper concentrations in the diagnosis of hypocuprosis in ruminants. Res Vet Sci 35:47

28. Aebi H (1974) Catalase. In: Bergemeyer HU (ed) Methods of enzymatic analysis. Academic Press, New York, pp 673-684

29. Paglia DE, Valentine WN (1967) Studies on the quantitative and qualitative characterization of erythrocyte glutathione peroxidase. J Lab Clin Med 70:158-169

30. Habig WH, Pabst MJ, Jakoby WB (1974) The first enzymatic step in mercapturic acid formation. J Biol Chem 249(22):7130-7139

31. Yilmaz C, İşcan M (2014) Glutathione S-Transferase activities and glutathione levels in needles of drought stressed Pinus Brutia Ten. Trees. Turk J Biochem 39(2):238-243

32. Yilmaz C, Bulus H, Oguztuzun S, Cihan M, Fidan C (2020) The activities of GST isozymes in stomach tissues of female obese patients. Turk J Biochem 45(6):883-889. https://doi.org/10.1515/tjb-20200235

33. Sedlak J, Lindsay RH (1968) Estimation of the total, protein-bound, and nonprotein sulfhydryl groups in tissue with Ellman's reagent. Anal Biochem 25(C):192-205. https://doi.org/10.1016/00032697(68)90092-4

34. Buege JA, Aust SD (1978) Microsomal lipid peroxidation. In: Methods in enzymology, vol 52. Academic Press, pp 302-310

35. Bradford MM (1976) A rapid and sensitive method for the quantitation of microgram quantities of protein utilizing the principle of protein-dye binding. Anal Biochem 72:248-254 
36. Hercog K, Maisanaba S, Filipič M, Sollner-Dolenc M, Kač L, Žegura B (2019) Genotoxic activity of bisphenol $A$ and its analogues bisphenol $\mathrm{S}$, bisphenol $\mathrm{F}$ and bisphenol $\mathrm{AF}$ and their mixtures in human hepatocellular carcinoma (HepG2) cells. Sci Total Environ 687:267-276. https://doi.org/10.1016/j.scitotenv.2019.05.486

37. Kose O, Rachidi W, Beal D, Erkekoglu P, Fayyad-Kazan H, Kocer Gumusel B (2020) The effects of different bisphenol derivatives on oxidative stress, DNA damage and DNA repair in RWPE-1 cells: A comparative study. J Appl Toxicol 40(5):643-654. https://doi.org/10.1002/jat.3934

38. Jambor T, Kovacikova E, Greifova H, Kovacik A, Libova L, Lukac N (2019) Assessment of the effective impact of bisphenols on mitochondrial activity and steroidogenesis in a dose-dependency in mice TM3 Leydig cells. Physiol Res 68(4):689-693. https://doi.org/10.33549/physiolres. 934200

39. Russo G, Capuozzo A, Barbato F, Irace C, Santamaria R, Grumetto L (2018) Cytotoxicity of seven bisphenol analogues compared to bisphenol $A$ and relationships with membrane affinity data. Chemosphere 201:432-440. https://doi.org/10.1016/j.chemosphere.2018.03.014

40. Maćczak A, Cyrkler M, Bukowska B, Michałowicz J (2017) Bisphenol A, bisphenol S, bisphenol F and bisphenol AF induce different oxidative stress and damage in human red blood cells (in vitro study). Toxicol In Vitro 41:143-149. https://doi.org/10.1016/j.tiv.2017.02.018

41. Modesto KA, Martinez CB (2010) Roundup ${ }^{\circledR}$ causes oxidative stress in liver and inhibits acetylcholinesterase in muscle and brain of the fish Prochilodus lineatus. Chemosphere 78:294-299. https://doi.org/10.1016/j.chemosphere.2009.10.047

42. Pigeolet E, Corbisier P, Houbion A, Lambert D, Michiels C, Raes M, Zachary MD, Remacle J (1990) Glutathione peroxidase, superoxide dismutase, and catalase inactivation by peroxides and oxygen derived free radicals. Mech Ageing Dev 51(3):283-297. https://doi.org/10.1016/00476374(90)90078-t

43. Dimitrova MST, Tsinova V, Velcheva V (1994) Combined effect of zinc and lead on the hepatic superoxide dismutase-catalase system in carp (Cyprinus carpio). Biochem Physiol C Toxicol 108:4346

44. Zhang R, Liu R, Zong W (2016) Bisphenol S interacts with catalase and induces oxidative stress in mouse liver and renal cells. J Agric Food Chem 64(34):6630-6640

45. Monteiro DA, Rantin FT, Kalinin AL (2009) The effects of selenium on oxidative stress biomarkers in the freshwater characid fish matrinxã, Brycon cephalus exposed to organophosphate insecticide Folisuper 600 BR®(methyl parathion). Biochem Physiol C Toxicol 149(1):40-49

46. Aykut $H$, Kaptaner $B(2021)$ In vitro effects of bisphenol $F$ on antioxidant system indicators in the isolated hepatocytes of rainbow trout (Oncorhyncus mykiss). Mol Biol Rep 48:2591-2599. https://doi.org/10.1007/s11033-021-06310-3

47. Meister A, Anderson ME (1983) Glutathione. Annu Rev Biochem 52(1):711-760

48. Wu M, Xu H, Shen Y, Qiu W, Yang M (2011) Oxidative stress in zebrafish embryos induced by shortterm exposure to bisphenol A, nonylphenol, and their mixture. Environ Toxicol Chem 30(10):23352341 
49. Stephensen E, Sturve J, Forlin L (2002) Effects of redox cycling compounds on glutathione content and activity of glutathione-related enzymes in rainbow trout liver. Comp Biochem Physiol C: Toxicol Pharmacol 133(3):435-442. https://doi.org/10.1016/s1532-0456(02)00129-1

50. Monterio DA, de Almeida JA, Rantin FT, Kalinin AL (2006) Oxidative stress biomarkers in the freshwater characid fish, Brycon cephalus, exposed to organophosphorus insecticide Folisuper 600 (methyl parathione). Comp Biochem Physiol C 143:141-149

51. El-Shenawy NS (2010) Effects of insecticides fenitrothion, endosulfan and abamectin on antioxidant parameters of isolated rat hepatocytes. Toxicol In Vitro 24:1148-1157

52. Eroglu A, Dogan Z, Kanak EG, Atli G, Canli M (2015) Effects of heavy metals (Cd, Cu, Cr, Pb, Zn) on fish glutathione metabolism. Environ Sci Pollut Res 22(5):3229-3237

53. Jung JH, Moon YS, Kim BM, Lee YM, Kim M, Rhee JS (2018) Comparative analysis of distinctive transcriptome profiles with biochemical evidence in bisphenol S- and benzo[a]pyrene-exposed liver tissues of the olive flounder Paralichthys olivaceus. PloS One 13(5):e0196425. https://doi.org/10.1371/journal.pone.0196425

54. Yu IT, Rhee JS, Raisuddin S, Lee JS (2008) Characterization of the glutathione S-transferase-Mu (GSTM) gene sequence and its expression in the hermaphroditic fish, Kryptolebias marmoratus as a function of development, gender type and chemical exposure. Chem Biol Interact 174(2):118-125. doi:10.1016/j.cbi.2008.05.011

55. Zare A, Henry D, Chua G, Gordon P, Habibi HR (2018) Differential hepatic gene expression profile of male fathead minnows exposed to daily varying dose of environmental contaminants individually and in mixture. Front Endocrinol 9:749. doi:10.3389/fendo.2018.00749

56. Li D, Chen Q, Cao J, Chen H, Li L, Cedergreen $\mathrm{N}$ et al (2016) The chronic effects of lignin-derived bisphenol and bisphenol A in Japanese medaka Oryzias latipes. Aquatic Toxicol 170:199-207. doi:10.1016/j.aquatox.2015.11.024

57. Sandamalika WMG, Priyathilaka TT, Lee S, Yang H, Lee J (2019) Immune and xenobiotic responses of glutathione S-Transferase theta (GST- $\theta$ ) from marine invertebrate disk abalone (Haliotis discus discus): With molecular characterization and functional analysis. Fish Shellfish Immunol 91:159171. doi:10.1016/j.fsi.2019.04.004

58. Pérez-López M, Anglade P, Bec-Ferté M, Debrauwer L, Perdu E, Cravedi JP, Rouimi P (2000) Characterization of hepatic and extrahepatic glutathione S-transferases in rainbow trout (Oncorhynchus mykiss) and their induction by 3,3',4,4'-tetrachlorobiphenyl. Fish Physiol Biochem 22:21-32. https://doi.org/10.1023/A:1007885332573

59. Coggan M, Flanagan JU, Parker MW, Vichai V, Pearson WR, Board PG (2002) Identification and characterization of GSTT3, a third murine Theta class glutathione transferase. Biochem J 366(1):323-332. doi:10.1042/bj20011878

60. Yin H, Xu L, Porter NA (2011) Free radical lipid peroxidation: mechanisms and analysis. Chem Rev 111(10):944-5972 
61. Ayala A, Muñoz MF, Argüelles S (2014) Lipid peroxidation: production, metabolism, and signaling mechanisms of malondialdehyde and 4-hydroxy-2-nonenal. Oxid Med Cell Longev 2014

62. Ullah H, Ambreen A, Ahsan N, Jahan S (2017) Bisphenol S induces oxidative stress and DNA damage in rat spermatozoa in vitro and disrupts daily sperm production in vivo. Toxicol Environ Chem 99(56):953-965

63. Ullah H, Jaha S, Ain QU, Shaheen G, Ahsan N (2016) Effect of bisphenol S exposure on male reproductive system of rats: A histological and biochemical study. Chemosphere 152:383-391

64. Ullah A, Pirzada M, Afsar T, Razak S, Almajwal A, Jahan S (2019) Effect of bisphenol F, an analog of bisphenol A, on the reproductive functions of male rats. Environ Health Prev Med 24(1):41. https://doi.org/10.1186/s12199-019-0797-5

\section{Figures}



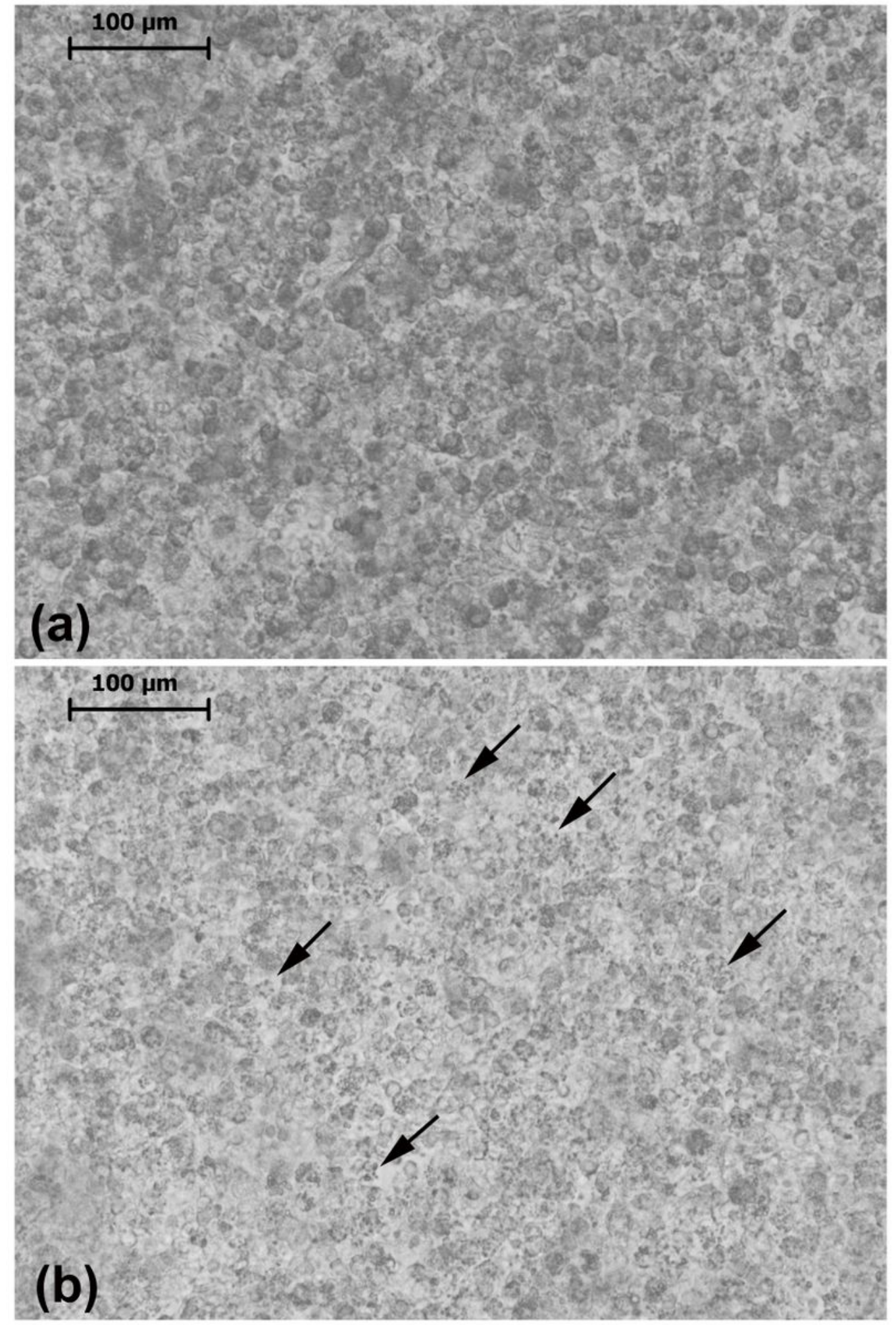

\section{Figure 1}

Photomicrographs showing the rainbow trout cultured hepatocytes. a healthy control cells clustering themselves into groups. b Cells that were exposed to a BPF concentration of $500 \mu \mathrm{M}$ for $24 \mathrm{~h}$, which display degenerative changes (shown with arrows). 


\section{LDH}

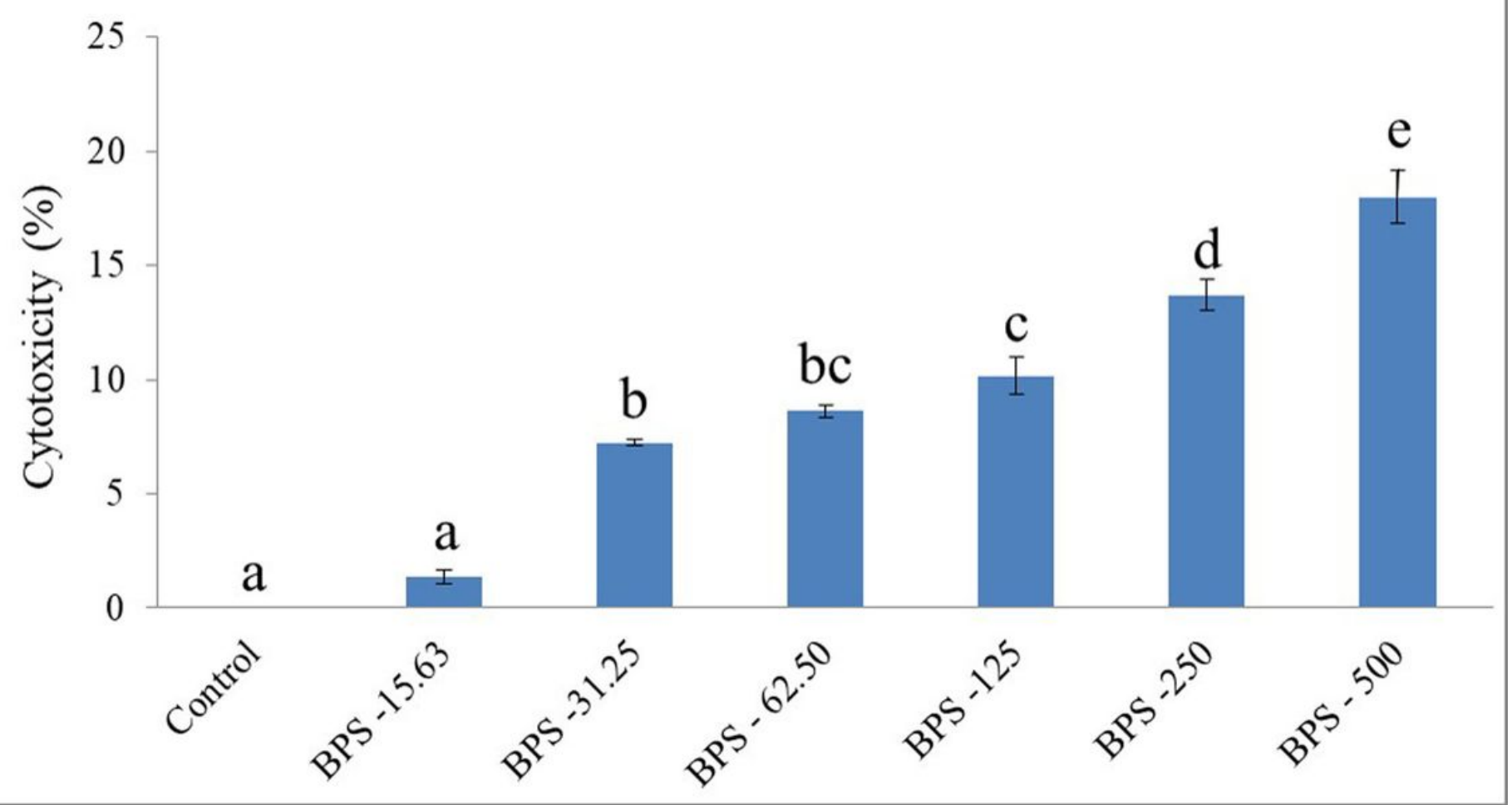

Figure 2

Graphs depicting the cytotoxic effects of the varying BPF concentrations on the rainbow trout cultured hepatocytes following exposure for $24 \mathrm{~h}$. The different letters shown indicate the statistically significant differences that were observed between the treatments.
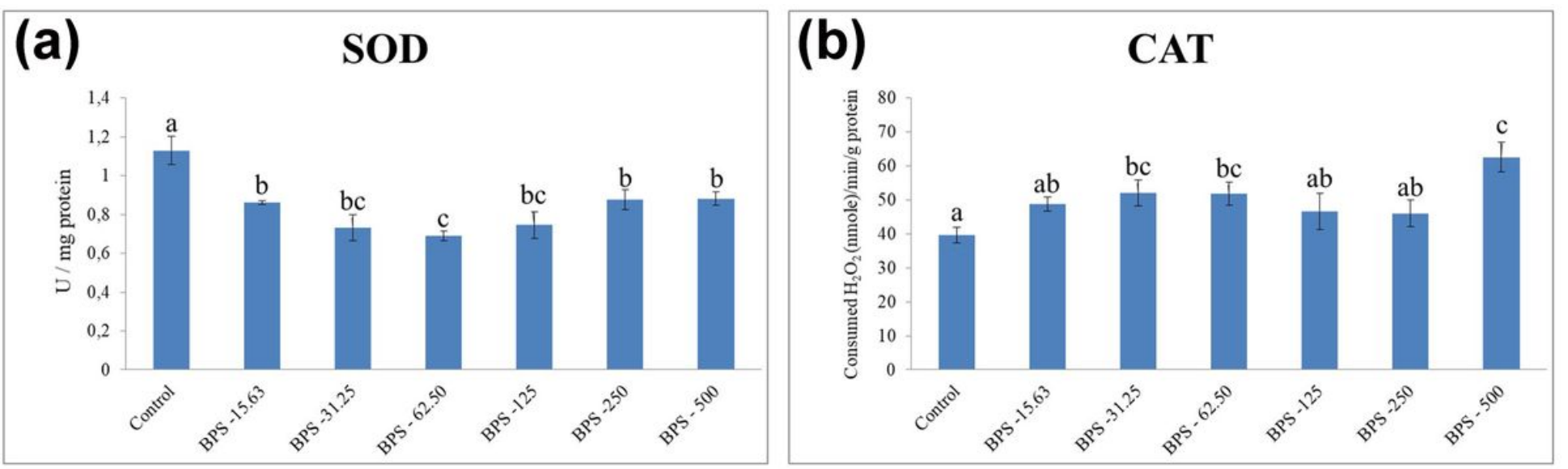

\section{Figure 3}

Graphs depicting the in vitro effects of the varying BPF concentrations on the a SOD and b CAT activity. The different letters shown indicate the statistically significant differences that were observed between the treatments. 

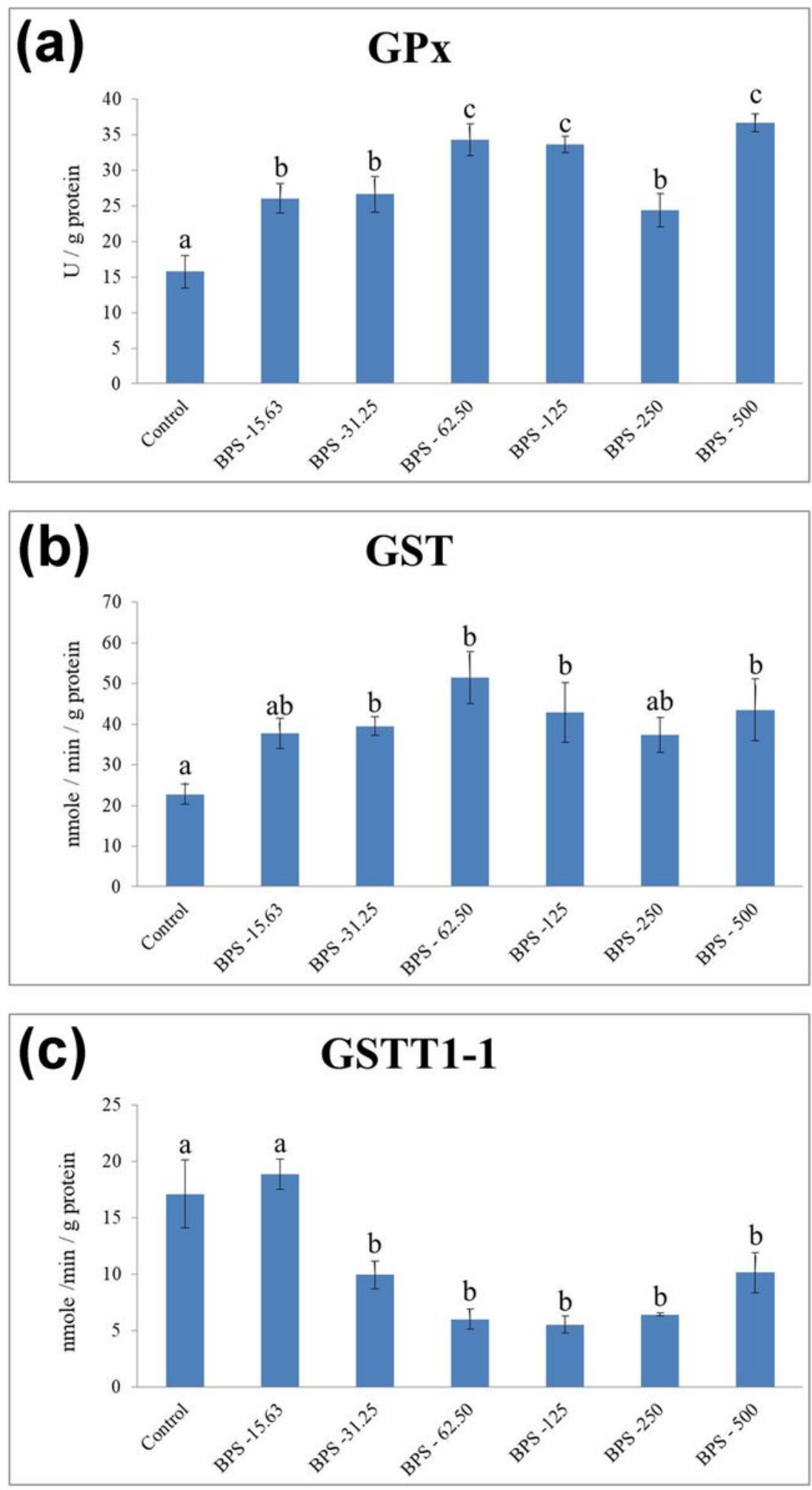

Figure 4

Graphs depicting the in vitro effects of the varying BPF concentrations on the a GPx, b GST, and c GSTT-1 activity. The different letters shown indicate the statistically significant differences that were observed between the treatments. 


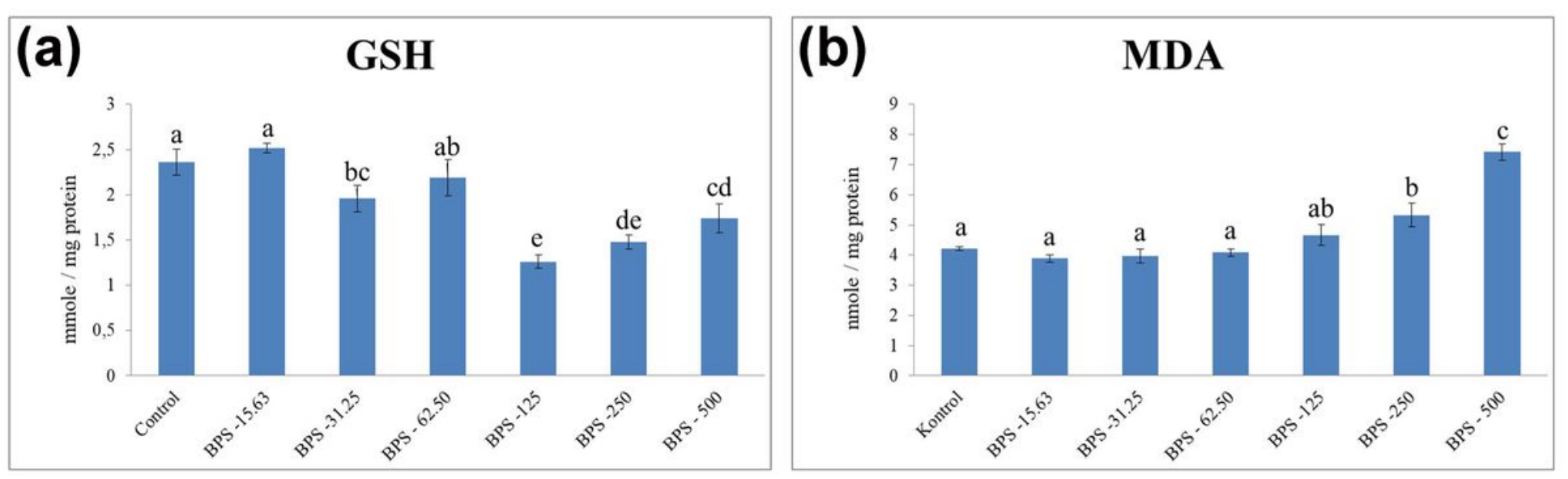

Figure 5

Graphs depicting the in vitro effects of the varying BPF concentrations on the a GSH and b MDA contents. The different letters shown indicate the statistically significant differences that were observed between the treatments. 